\title{
Can Women be Successful Managers in Technology Business? four Romanian Examples
}

\author{
Andreea BRUJBAN \\ University "Politehnica" of Bucharest, Romania \\ andreeabrujban@gmail.com \\ Cezar SCARLAT \\ University "Politehnica" of Bucharest, Romania \\ cezarscarlat@yahoo.com \\ Alexandra IOANID \\ University "Politehnica" of Bucharest, Romania \\ ioanid.alexandra@gmail.com
}

\begin{abstract}
Purpose of the work: This research is meant to outline the contribution brought by women in technology management and identify how business environment, especially from the Romanian market, welcome females who lead in this men dominated industry. Methodology: The paper has been built upon analyzing the connection between world's female leaders and technological advance. The sources were articles, books and interviews. To outline the Romanian situation, an interviewing phase followed, with four women who currently lead in the IT industry.

Important finding: Gender disparity has been and is wide-reaching in most of technology's industries. Nevertheless, women reaching a certain career level, are more eager to embrace tech management. They have proven to be extremely open to the challenges brought by this new technologized working environment, worldwide in general and narrowed down to Romania as well.

Conclusions and key "Take Home Messages": The primary message transmitted by this research is that women can indeed add value to the technology business and their main contribution is bringing IT closer to people. Women's potential reaches beyond having gender diversity, and should be exploited at its maximum. Women have the understanding that technology is created for people, and their entire work revolves around it.
\end{abstract}

Keywords: women, management, technology, success

\section{WHY IS THE ROLE OF WOMEN IN TECH LEADERSHIP IMPORTANT?}

The global carousel revolves nowadays around technology. We are facing outstanding innovations which have as main goal bringing people together. This new world of 
networking, socializing and access to information has been driven in the recent years by the business leaders of technology market. And there is one crucial aspect to be taken into account: women are considerably less present among IT leaders.

Why are we not making more progress with our women? Is not that we do not have great women. We do, we have amazing women. Why are they not coming all the way through the pipeline?

There are two major reasons why studying and understanding gender disparity in companies' management, especially in the technological domain, is critical.

First, women represent half of the talent pool, globally speaking (European Commission, 2012). And isn't it essential for companies to have the best brains, especially in times of great evolution?

Second, one must find answers to the following: does it really matter for corporations to have women in leading positions?

The answer lies in the steps forward taken by all large companies which embraced personnel diversity. Having employees with the same profile sitting at a negotiation table leads to a fast, yet poor conclusion. It also lies in the success of women CEOs around the globe, running some of the most profitable tech companies. Sustainable economies understand the equilibrium brought by women professionals and embrace it as a natural contribution to long term profit. In the same way, a healthy sustainable society will treat both men and women based on worth, not gender. Yes, they are different, but this is nothing but a positive aspect in both business and day to day life. So if women's presence deserves a boost, why are they still not as present as men? Broadly because mind-sets need to adjust.

Women in management still face difficulties in their advance, women in IT are often labeled. They themselves seldom restrain from doing what they are passionate about, due to the external context.

The great side is that women leaders around the world prove that boundaries can be surpassed. They serve as models of perseverance and success. Either one speaks about business, technology or politics, the contribution of women is more and more visible, even outstanding. And their traces show that women belong in the current global scene.

This article aims an emphasis on women's value added in IT, by bringing in front four of Romania's managers and their special contribution. Its content will thus reveal the role of liaison that women have in tech business and how this market gains from the bridges women build.

\section{HOW DOES THE WORLD SEE GENDER DISPARITY IN IT?}

As companies transform, and human talent finds itself in a new geographical dispersion, human resource management ought to be approached in a brand new way. Societies' evolution helped acknowledging the female labor supply potential and the idea of them blending in for a plus of productivity. Still, as the technological slope began rising, this 
gender inequality strengthened and the world faced a mass association of IT scientists with man. How was this gender unbalance in IT reached? The answer comes from two primary drivers: society and women.

On one side, there are faults in the industry caused by people's general beliefs. Most employers associate engineers with a male figure. They perceive men as more inclined towards fact, figures. They predict how inborn skills will make them more passionate and efficient. Also, women are seen as less reliable. An old, yet current idea still governs employment decisions: women do not build careers, they simply pursue casual works that take second place to familial concerns. The intermittency of their work has often been a reason of concern, and in technology business this concern has even a higher impact. Moreover, employers see men as more willing to take risks, whilst women are perceived as more reluctant to change (Johnson, Fox \& Rosser, 2006). In an industry that requires permanent innovation, this perception is a huge downgrade for women.

On the other edge of this vicious circle, lays women self-perception of their abilities: females rating themselves lower than males with similar abilities. They often fail to understand the importance of their work, the value added they could bring to the technological flow. Often, when faced with a male dominated context, women get really busy trying to figure out whether or not they belong there. It seems more welcoming and at ease for them to target jobs with a gender balanced ratio, or better female dominated ones.

This "belonging" need is a combination of social stereotypes and comfort of women worldwide. Thus the main drawback is that within tech business, women are treated as a special group. This phenomenon has been justified in the latest decade as an effect of "intersectionality" (Bystydzienski, Eisenhart \& Bruning, 2015), a concept that explains how social divisions (e.g. gender, race, age) are directly connected to career choices. The attempt is to find main causes, cut them out, and create a framework that would welcome more women in IT as a natural process, not as a peculiar turn of events. Gladly, several iconic women have managed to break societies' categorization and are now among world's most successful IT leaders. They serve as role models for young girls willing to pursue a career in technology, as their contribution has changed the way society perceives women's leadership potential in this field.

Research on world's female managers has revealed optimistic patterns. Although the disparity between men and women in technology professions is still at high levels, studies show that most successful women in the world have majored in engineering. Also, the number of women leaders who brought their companies among the most successful firms in the world has been in continuous increase from the end of $20^{\text {th }}$ century. Moreover, despite of the widespread perception of women as "casual workers" due to involvement in family life, more than $80 \%$ of female CEOs have children (Saskia, 2014).

In order to bring empirical arguments to the table, the following lines shall introduce world's most renowned female super achievers, who built their career in a male dominated framework. 
One of the most present appearances on today's global scene is undoubtedly Caroline Fiorina. Her visibility is rooted both in outstanding tech management and political involvement, being one of the 2016 candidates for USA presidency. Technology and Politics have several common aspects, and one of the most important seems to be the gender discrepancy. Fiorina managed not only to rise herself as a female manager, but to reduce the male-female gap within HP, especially at managerial level. Within an interview for World News, Fiorina emphasized the gender disparity in the Silicon Valley and agreed that a change is stringently needed. In business, she says, when at a table you have similar people, people of same color, gender, of similar ages, you will reach a conclusion fast. But the impact of that decision will be low. And just as businesses need variety, so do country leaders.

The co-president of Oracle, Safra Catz, proves once again the benefits of women in tech. Based on her and her team's strategies, Oracle not only provides top quality services on the tech market, but also dominates the database field. Catz's skill to oversee Merger and Acquisition opportunities combined with outstanding deal making attributes set the basis of success at Oracle.

This brief analysis of global tech leadership scene cannot end without mentioning the bright, outstanding Marissa Mayer. Marissa has been a key player in the design of Google's era-defining homepage; her logic and design sense are now woven into the daily lives of people at every corner of the globe. In an interview for Makers, Marissa calls her evolution as "gender oblivious". She remembers how one day, while she was in the university, she found in the newspaper a brief article about "the blonde girl in computer science". And it took her a while to understand that that blonde girl was herself, and that for others she is different. No one knew at that time how big programming will grow; but Marissa knew for sure that she wants to code. After years of coding, she continues to be impressed by the wonders a computer can do.

Female super achievers worldwide are risk takers and have vision. They embrace innovation and tech advance, and understand the benefit it brings to their professional activities. With respect to the belief that women do not feel comfortable in a male dominated industry, there has been a recent bias to a turn on perception. Both women and men should do whatever they feel passionate about, without worrying about how they fit in. Pursuant to this comprehensive approach of what happens to the women leaders around the globe, it is time to broaden the analysis and take it on the Romanian IT market.

\section{THE ROMANIAN MODEL - FOUR WOMEN MANAGERS SUSTAINING INNOVATION}

In order to identify how leader women feel in the Romanian technological framework and what is their special contribution, four amazing ladies, managers in software technology, have been involved in throughout discussion about their careers and what happens beyond it as well. 
Their answers and reactions prove how Romania embraces female leadership in domains that were traditionally perceived as men's fields. Moreover, their activity shows why female workforce is important for IT innovation and progress.

\section{Research context}

Within three months of primary research (February to April 2015) women who have chosen to lead in technology on the Romanian market have been identified and contacted. This revealed how the visibility gained by women managers lately increased. Gladly Romania appears to be making progress, which corresponds to the international ascending attention brought to women leaders.

The main sources have been awarding events, such as "Women in Tech" organized by Intel or "Women in Technology Awards", held by Market Watch. Also a great starting point was represented by the online communities Girls in Tech Romania and Girls Who Code.

Four out of the contacted managers have given a positive feedback and all participated to a throughout discussion about their career in technology.

\section{Interview guide}

The following set of questions has been adapted upon the interviewee's analysis (educational and professional background, marital status, position within the company). Furthermore, in the context of a face to face conversation, additional questions resulted along the way. Nevertheless, the below remain essential for drawing relevant conclusions:

(A) How did the closeness to IT happen?

(B) Which is the pattern of your education and career?

(C) You are now a professional in a men-dominated field. How is the interaction with colleagues/ subordinates/ partners?

(D) What would be your particular role as a woman in IT? Do you find it different from a man's contribution?

(E) Which would be the best part of being a female manager in IT?

(F) How about a downside of it? Which are the obstacles?

(G) Do your personal goals meet the professional ones? Do you believe that a woman's role in a family can compromise career?

All interviews were conducted face to face, for a more at ease interaction.

The profile of the four young women managers (age range 25-35) who provided positive feedback to this initiative can be summarized as presented in Table 1. 
Table 1. Profile of interviewed Romanian female managers in technology

\begin{tabular}{|l|l|l|l|}
\hline \multicolumn{1}{|c|}{ Name } & Position & Company & \multicolumn{1}{|c|}{ IT area } \\
\hline $\begin{array}{l}\text { Sabina David } \\
\text { "As a woman in technology, you have } \\
\text { to be prepared all the time" }\end{array}$ & $\begin{array}{l}\text { Project } \\
\text { Manager }\end{array}$ & $\begin{array}{l}\text { Iristel } \\
\text { Canada }\end{array}$ & Telecom \\
\hline $\begin{array}{l}\text { Irina Oprea } \\
\text { "A lady should wear more than one } \\
\text { hat" }\end{array}$ & CEO & $\begin{array}{l}\text { System } \\
\text { Innovation }\end{array}$ & $\begin{array}{l}\text { SAP } \\
\text { Business } \\
\text { Consulting }\end{array}$ \\
\hline $\begin{array}{l}\text { Elena Bogasiu } \\
\text { "Coding is like writing. When you see } \\
\text { your result serving million people, you } \\
\text { get as thrilled as a writer seeing their } \\
\text { book on bookstores shelves." }\end{array}$ & $\begin{array}{l}\text { Deam } \\
\text { Leader }\end{array}$ & BRD & $\begin{array}{l}\text { Cobol } \\
\text { development }\end{array}$ \\
\hline $\begin{array}{l}\text { Alice Porosanu } \\
\text { "I do not remember being encouraged } \\
\text { by parents } \text { or teachers to do science. It } \\
\text { was the type of qualification that } \\
\text { women were not identified with." }\end{array}$ & $\begin{array}{l}\text { Ceam } \\
\text { Leader }\end{array}$ & Nobel & Telecom \\
\hline
\end{tabular}

Another relevant aspect is that two of the interviewees have children, aged between 1 and 2 years old.

The interviewing phase aimed mainly to determine the particular contribution that women managers bring to the Romanian technology market.

Additional results are related to women's development as IT professionals in Romania, their study and career path, how did they choose technology and how do they feel in this position. Furthermore, it has been interesting to observe the correlation between family and work, especially since the personal life of a woman is considered to get in front of her career.

\section{Main deductions from the Interviewing Phase - Romania does nurture women's professional goals}

The following lines will reveal how women feel as tech professionals in Romania. Questions of the interviews have been centralized and narrowed to the crucial topics, namely society's perception, self-awareness as well as personal goals versus professional advance.

(A) Feedback about Romania and IT possibilities for women

Sabina: "At this point, I would not leave Romania. Here I had the chance to do all I wanted to, work related. I never hit unmanageable obstacles. I have got in touch even with the Western world; nothing motivated me enough to leave. Gender-wise they were even a bit more hostile, maybe more aware. I have noticed also how women in IT from other countries try hard to fit in. I never have to do so here. I have been myself and learned along the way." 
Irina: "As a matter of fact, I was never keen on another country. Here is my home, and Romania is actually a great country to be in, especially at this level. I have worked in USA many years ago, for several months, I never returned. I have been to Asia with business. There it feels difficult to be a woman even on the streets. Professional-wise, I have grown so much in Romania that I know it suits a leading women perfectly."

Elena: "If I did leave the country, it would be solely for the education of my little girl, not for me working in a different environment. I experienced this for several months in Franca and Belgium; I couldn't wait to come back."

Alice: "World's best IT companies open branches here in Romania, why would someone passionate for software leave?"

At this point, one may see how well integrated these women managers are in the Romanian business environment. They all see Romania as a welcoming environment, for IT professionals, women leaders in business and women involved in IT altogether.

Indeed, they all experienced at some point, either at the beginning of their career, or during their advance, a certain degree of reluctance gender related. Yet in the same time, while travelling in different countries, they understood that this same reluctance towards women leaders can be even more emphasized abroad. Consequently none of the interviewed women expressed any intention of leaving the country for better professional opportunities.

\section{(B) External reaction to their involvement in technology management}

Sabina: "At the beginning of my managing experience, I did have the tendency to be too straight forward or too rough. Looking behind, I see it was a way of mine to compensate the fact that I was a young girl trying to be a manager in technology. So yes, I had various approaches, because you tend to be the pretty face if you make the slightest mistake. As a woman in technology, you have to be prepared all the time. You must be able to back up any idea you have, anything you say. Because at the smallest mistake, people can easily label you as the pretty face."

Irina: "I consider our product has always been more important than who delivered it. I have been abroad indeed, in more than 20 countries, and the solution always matters the most. I even believe that Romania is one of the many open-minded societies, where you can be whoever you want to, as long as you work for it. "

Elena: "As a matter of fact I was for a long time perfectly unaware of such differences between men and women in technology! The first time I heard about this, was when a French partner came on a business trip here in Bucharest and we went for lunch. He asked me if employers here differentiate between females and males professionals."

Alice: "We have unfortunately few role models in many scientific fields, including telecom and networking. This is probably why I do not remember being encouraged by parents or teachers to do science. It was the type of qualification that women were not identified with. 
More women should be seen doing science. Moreover, I believe that they should be less obvious about their gender. What I mean is that people should respect you for your achievements, not because you are a male or a female."

\section{(C) Personal goals versus professional advance}

When asked if their personal goals could stand against career evolution, they all answered nearly the same. Family is not a drawback, not for women in IT and not for women activating in other fields.

On the contrary, having a fulfilling personal life is a huge motivating factor.

The two interviewees already having small children said that they were indeed somehow forced into returning faster from maternity leave. They sensed a pressure from their upper management. Nevertheless, their professional advance per say has not been affected in any way, as they do not consider the time spent with their children a career drawback, but a normal life decision, one that improved their lives.

In order to get this family discussion further, the topic of ovarian tissue freezing was brought into discussion and thus the possibility to postpone having children until the career path is settled. None of the interviewed women saw it as a necessity, being given their above stated perspective. Furthermore, they did not see it as a viable solution due to the very large age gap. As they saw it, having a child at 40 years old implies a crucial difference in understanding and complying with the changed ways of living. Societies evolve so fast, technology is launching in a tremendous advance, people live differently and new generations are already arising. Thus raising a small baby 20 years for now did seem like a great challenge for the interviewed women.

\section{(D) Special contribution to technology business}

The general conclusion with respect to this topic is the following: women bring technology closer to people. They have the empathic approach, and manage to find the human side of software.

Regarding leadership itself, the interviewed women impressed me through their ability to impose themselves in their working environment. They place their success on the high quality professional activity undertaken. As these ladies view it, gender becomes irrelevant when your results meet all expectations.

\section{CONCLUSION:}

\section{IS THE WORLD READY FOR WOMEN LEADERS IN TECH?}

Because women are for sure ready to lead in technology.

Gender disparity has of course been pervasive and wide-reaching in most of technology's industries. Yet with the rise of this information society, women are now given the opportunity to speak up, share their ideas and get credit for their contributions. 
The respondents' views on external and internal attitude towards women in tech industries - as well as on family and particular contributions brought by women in technology industries - are presented in Appendix 1 (Table A1 and Table A2 respectively).

The conducted interviews demonstrate how women have changed their perception on IT. They are aware of the degree in which technology impacts people. Even more, they see IT as the means to reach societies and change life-styles, which is nothing but true. Bold, talented, passionate women can be managers, despite the degree of uncertainty brought by these male dominated fields. And once they reach a certain level, they discover another layer of the society, a threshold of the courageous, inspiring people, having their minds open to variety.

This entire study leads to an encouraging conclusion: more and more women are aware of technology's potential, and in the same time IT benefits increasingly from these women's contribution. Female managers of today's technologized world bring software and hardware closer to the people these serve. Because after all machines and programs are built to serve people, and yet not the other way around.

\section{RESEARCH LIMITATIONS AND POTENTIAL FURTHER ACTIONS}

The main purpose of this research has been to identify how women managers contribute to the Romanian technological market, namely which is the value-added they bring, and how they feel in the leadership positions occupied.

Should the sample be enlarged, the conclusions of the study would become representative for the entire Romanian technology market. The research would then provide as a strong analysis of women' leaders in tech position towards their profession the business environment. It would draw a pattern of female managers' evolution in the IT industry and even the basis for prospects.

\section{Appendix 1.}

Table A1. Respondents' view on external and internal attitude towards women in technology industries

\begin{tabular}{|c|c|c|c|c|}
\hline TOPIC & \multicolumn{2}{|c|}{$\begin{array}{c}\text { Societies' Perception on Women } \\
\text { in Tech }\end{array}$} & \multicolumn{2}{c|}{ Women Self Awareness } \\
\hline $\begin{array}{c}\text { Elena } \\
\text { Bogasiu }\end{array}$ & Positive & $\begin{array}{c}\text { Not aware of gender } \\
\text { barriers to women in } \\
\text { tech; evolution based } \\
\text { on her objectives }\end{array}$ & Positive & $\begin{array}{c}\text { Beginning: did not } \\
\text { trust herself enough } \\
\text { to aim very high; } \\
\text { after having a job, she } \\
\text { earned confidence }\end{array}$ \\
\hline
\end{tabular}




\begin{tabular}{|c|c|c|c|c|}
\hline $\begin{array}{c}\text { Irina } \\
\text { Oprea }\end{array}$ & Positive & $\begin{array}{c}\text { Unlike Asian societies, } \\
\text { Romania proved to be } \\
\text { rather welcoming and } \\
\text { open-minded }\end{array}$ & Positive & $\begin{array}{c}\text { Always confident, } \\
\text { which lead to a rather } \\
\text { smooth professional } \\
\text { and personal } \\
\text { evolution. }\end{array}$ \\
\hline $\begin{array}{c}\text { Sabina } \\
\text { David }\end{array}$ & Negative & $\begin{array}{c}\text { Met some external } \\
\text { obstacles here and } \\
\text { abroad: protective } \\
\text { men, reluctant to her } \\
\text { abilities or role }\end{array}$ & Positive & $\begin{array}{c}\text { Gained trust along the } \\
\text { way, based on her } \\
\text { results and feedback }\end{array}$ \\
\hline $\begin{array}{c}\text { Alice } \\
\text { Porosan }\end{array}$ & Negative & $\begin{array}{c}\text { Her family and friends } \\
\text { did not support her } \\
\text { career choices; tech } \\
\text { field would not be } \\
\text { associated with women }\end{array}$ & Positive & $\begin{array}{c}\text { Passionate about the } \\
\text { field, always focused } \\
\text { on work and aware of } \\
\text { her competencies }\end{array}$ \\
\hline
\end{tabular}

Table A2. Respondents' view on family and particular contributions brought by women in technology industries

\begin{tabular}{|c|c|c|c|c|}
\hline TOPIC & Personal & ersus Professional Goals & $\begin{array}{r}\text { Value A } \\
\text { (di }\end{array}$ & $\begin{array}{l}\text { ded to Tech Business } \\
\text { rent from men) }\end{array}$ \\
\hline $\begin{array}{l}\text { Elena } \\
\text { Bogasiu }\end{array}$ & Negative & $\begin{array}{l}\text { Although she has a } \\
\text { fulfilled personal life, she } \\
\text { met several obstacles } \\
\text { along the way; believes it } \\
\text { is difficult to have them } \\
\text { both }\end{array}$ & Negative & $\begin{array}{l}\text { Same contribution as } \\
\text { men, does not } \\
\text { perceive herself to be } \\
\text { a different } \\
\text { professional; } \\
\text { communication may } \\
\text { be different, yet not } \\
\text { seen as a crucial } \\
\text { aspect }\end{array}$ \\
\hline $\begin{array}{l}\text { Irina } \\
\text { Oprea }\end{array}$ & Positive & $\begin{array}{l}\text { Admits that it is hard to } \\
\text { keep a balance, yet thinks } \\
\text { it is normal and possible } \\
\text { to explore every aspect of } \\
\text { life }\end{array}$ & Negative & $\begin{array}{l}\text { Although sees women } \\
\text { as more emphatic, the } \\
\text { general opinion is that } \\
\text { both male and female } \\
\text { contribution consists } \\
\text { in results }\end{array}$ \\
\hline $\begin{array}{l}\text { Sabina } \\
\text { David }\end{array}$ & Positive & $\begin{array}{l}\text { Profession only cannot } \\
\text { fulfill and personal plans } \\
\text { do not affect job } \\
\text { efficiency; on the } \\
\text { contrary it can be } \\
\text { motivating }\end{array}$ & Positive & $\begin{array}{l}\text { Making IT more } \\
\text { human, bringing } \\
\text { hardware and } \\
\text { software closer to } \\
\text { people; building } \\
\text { bridges through } \\
\text { effective } \\
\text { communication }\end{array}$ \\
\hline
\end{tabular}




\begin{tabular}{|l|l|c|l|c|}
\hline $\begin{array}{l}\text { Alice } \\
\text { Porosan } \\
\mathbf{u}\end{array}$ & Positive & $\begin{array}{c}\text { A husband, a child, } \\
\text { friends do not make a } \\
\text { woman less of a } \\
\text { professional. It should } \\
\text { not be about time spent at } \\
\text { work, but about } \\
\text { efficiency }\end{array}$ & & $\begin{array}{c}\text { Going beyond } \\
\text { technicalities and } \\
\text { experiencing the end- } \\
\text { user approach }\end{array}$ \\
& $\begin{array}{c}\text { Positive } \\
\text { y. }\end{array}$ & & \\
\hline
\end{tabular}

\section{REFERENCES}

Bystydzienski, J., Eisenhart,M. \& Bruning, M. (2015). Intersectionality as a Framework for Understanding Diverse Young Girl's Commitment to Engineering, Journal of Women in Minorities and Science Engineering, Volume 21, 1-26.

European Commission (2012). Women on boards - Factsheet 1: The economic arguments. Gender Equality Files. Retrieved December, 2014, from http://ec.europa.eu/justice/gender-equality/files

Johnson D. G., Fox M., \& Rosser S. (2006). Women, Gender and Technology, Illinois, USA: University of Illinois.

MAKERS Profile: Marissa Mayer, Retrieved March 10, 2015 from http://www.makers.com/marissa-mayer

Malloy J. (2003). Women, Art and Technology, Massachusetts, USA: Massachusetts Institute of Technology.

Rapp. Saskia Jensen (2014). Women CEOs in the Fortune 1000: By the numbers. Retrieved May 2015 from http://fortune.com/2014/07/08/women-ceos-fortune-500-1000/ 